\title{
Phytochemical Screening, Total Flavonoid and Total Phenolic Content and Antioxidant Activity of Different Parts of Caesalpinia bonduc (L.) Roxb
}

\author{
Elin Novia Sembiring, Berna Elya, Rani Sauriasari
}

\section{Elin Novia Sembiring, Berna Elya, Rani Sauriasari}

Faculty of Pharmacy, University of Indonesia, Depok, 16424, INDONESIA.

\section{Correspondence}

Berna Elya

Faculty of Pharmacy, University of Indonesia, Depok 16424, INDONESIA

Phone No: +6281314161497

E-mail: berna.elya@farmasi.ui.ac.id

\section{History}

- Submission Date: 02-10-2017.

- Review completed: 27-10-2017;

- Accepted Date: 20-10-2017

DOI : 10.5530/pj.2018.1.22

Article Available online http://www.phcogj.com/v10/i1

\section{Copyright}

(C) 2018 Phcog.Net. This is an openaccess article distributed under the terms of the Creative Commons Attribution 4.0 International license.

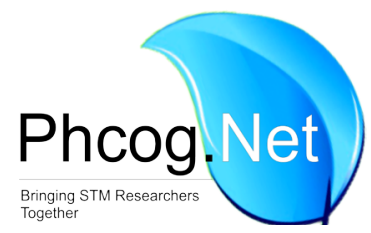

\begin{abstract}
Background: Caesalpinia bonduc (L.) Roxb are traditionally used in Indonesia to treat various diseases, but still limited study about different part of this plant. Objective: The aim of this study was to screen the phytochemicals, to evaluate the total flavonoid and total phenolic contents as well as antioxidant activity of ethanol extract of root, stem, leaves, and seed kernel of C. bonduc. Methods: Each part of plant were extracted by reflux using $70 \%$ ethanol as the solvent for $2 \mathrm{~h}$ and repeated 3 times. Total flavonoid content was determined by aluminium chloride colorimetric assay on $415 \mathrm{~nm}$. Total phenolic content was determined with Folin-Ciocalteu 1:4 on $765 \mathrm{~nm}$ using microplate reader. Antioxidant activity was determined using 2,2-diphenyl-1-picrylhydrazyl (DPPH) free radical scavenger methods. Results: Phytochemical screening showed that all of samples positively contain flavonoid and saponin. Total flavonoid content was the highest in leaf and the lowest in root whereas total phenols content was highest in leaf and the lowest in seed kernel. The crude extracts displayed DPPH free radical scavenging activity with highest value in leaf extract followed by root, stem, and seed kernel. Conclusion: The $70 \%$ ethanol leaf extract of C. bonduc showed the highest yield, total flavonoid content and total phenolic content among other parts investigated. Moreover, leaf extract has highest DPPH free radical scavenging activity $(79.802 \mu \mathrm{g} / \mathrm{ml})$ which could be related to its higher phenolic content.

Key words: Caesalpinia bonduc, Phytochemical screening, DPPH, Total flavonoid, Total phenolic content.
\end{abstract}

\section{INTRODUCTION}

Genus of Caesalpinia comprise more than 500 species, which have many beneficial effects for humans health based on their pharmacological activity. ${ }^{1}$ One of medicinal plant from this genus was Caesalpinia bonduc (L.) Roxb (syn. Caesalpinia bonducella (L.) Flemming, Caesalpinia crista (Linn)), from Fabaceae family. ${ }^{2,3}$ This plant was grown in Indonesia, which is one of country in the world with rich source of medicinal plants. ${ }^{4} \mathrm{C}$. bonduc also distributed in other tropical and subtropical part of Asia, such as India, Shrilanka, Vietnam, China, Myanmar and Bangladesh. ${ }^{5}$ In Indonesia, C. bonduc known as Bagore, Kalici, Tinglur, Areuy Matahiang. ${ }^{6,7}$

C. bonduc is thorny perennial shrub with length reach of $15 \mathrm{~m}$, stems are covered in curved spines. It's about $2 \mathrm{~cm}$ gray seeds known as nicker nuts. The kernel is about $1.23-1.75 \mathrm{~cm}$ in diameter with hard, pale yellowish - white, circular to oval, furrowed and ridged surface. Branches are armed with hooked and straight hard yellow prickles. Leaves are bipinnate, $25-40 \mathrm{~cm}$ long and petioles prickly. Leaflets 7-9 pairs, ovate-elliptic, $1.5-3.5 \times 1-2 \mathrm{~cm}$, glabrous above, and pubescent below. Stipules are foliaceous. Peduncle is long, 3 to $4 \mathrm{~cm}$, prickled, bracts long, linear-lanceolate and deciduous. Pedicel is $0.5-1.5 \mathrm{~cm}$ and very short in bud. ${ }^{2,7,8}$ Each part of the plant as seen in Figure 1. Whole plant of the C. bonduc contain steroidal saponins, fatty acids, hydrocarbons, phytosterols, isoflavone, amino acids and phenolics. ${ }^{2}$ Caesalpinins $\mathrm{H}-\mathrm{P}$ and norcaesalpinin $\mathrm{F}$ were isolated from the $\mathrm{CH}_{2} \mathrm{Cl}_{2}$ extract of the seed kernels of Caesalpinia crista, together with 13 known diterpenes. ${ }^{9}$

In Indonesia, seed kernel of this plant traditionally used for cough, malaria, and as anthelmintic., Leaves for inflammation and liver disease, and the root was used for gastric and blood disorder. ${ }^{6,7}$ Part of C. bonduc possesses several activities such as anthelmintic, antimalaria, antidiabetic, antioxidant, antibacterial, antimalarial and antidiarrhoeal. ${ }^{2,11,12}$

Antioxidants could be used for management of some pathophysiological conditions, which involve free radical, such as cardiovascular and neurodegenerative disease..$^{13}$ One established in vitro method to evaluate antioxidant activity was DPPH scavenging activity. This method is furthermore rapid, not involved with many steps and reagents, and

Cite this article: Sembiring EN, Elya B, Sauriasari R. Phytochemical Screening, Total Flavonoid and Total Phenolic Content, and Antioxidant Activity of Different Parts of Caesalpinia bonduc (L.) Roxb. Pharmacog J. 2018;10(1):123-7. 
inexpensive compare to other method. ${ }^{14}$ Flavonoid and phenolic compounds may be useful as antioxidant from natural sources. Distribution of phenolic compounds varies between different parts of plant. ${ }^{15}$

According to the literature search, phytochemical and antioxidant activity of different parts of $C$. bonduc have never been comparatively evaluated. The study was carried out to screen the phytochemicals as well as to evaluate total flavonoid contents, total phenolic contents and antioxidant activity of root, stem, leaf and seed kernel ethanolic extract.

\section{MATERIAL AND METHODS}

\section{Chemicals}

Gallic acid, Foline-Ciocalteu reagent, 1,1-diphenyl-2-picrylhydrazyl (DPPH), ascorbic acid, quercetin, aluminium chloride, sodium acetate, sodium carbonate was purchased from Sigma Aldrich (Singapore). Ethanol were purchased from Merck (Germany).

\section{Plant Materials}

Parts of C. bonduc were collected in January 2017 from Bulukumba, South Sulawesi, Indonesia. All plants were identified by Indonesia Science Institution, Center for Plant Conservation-Bogor Botanical Garden, Indonesia.

\section{Preparation of Samples}

The plants materials were collected and cleaned, dried at room temperature, crushed into powder and stored in an air tight glass container. Fifty $\mathrm{g}$ of powdered samples was extracted by reflux using $70 \%$ ethanol as the solvent for $2 \mathrm{~h}$ and repeated 3 times. The extracts then evaporated using a vacuum rotatory evaporator, and then dried in water bath on $50^{\circ} \mathrm{C}$.

\section{Determination of Percentage Yield (\%)}

The percentage yield of the extract was determined using the dry weight of extract (a) and soaked samples material (b) using the formula:

$$
\text { Percentage yield }(\%)=\mathrm{a} / \mathrm{b} \times 100
$$

The extraction yield was calculated for each extract.

\section{Phytochemical Screening}

The qualitative phytochemistry test were conducted according to Indonesian Materia Medica ${ }^{16}$ and Harborne. ${ }^{17}$ Alkaloid test with Mayer, Dragendorff, and Bouchardat reagents; flavonoid test with Shinoda test; tannin test with gelatin test, gelatin-salt test, and test with ferrous (III) chloride; saponin test with froth test; quinone with Borntrager test; terpenoid/steroid test with Liebermann-Burchard reagent.

\section{Determination of Total Flavonoid Content}

Total flavonoid content was determined by aluminium chloride colorimetric assay adapted from Chatatikun et at ${ }^{18}$ and Roy et al ${ }^{19}$ with slight modification. Standard solution of quercetin in concentration $30,40,50,60,70,80,90,100 \mu \mathrm{g} / \mathrm{ml}$ were prepared in $96 \%$ ethanol. $50 \mu \mathrm{l}$ of extracts $(1 \mathrm{mg} / \mathrm{ml})$ or standard solution was added to $10 \mu \mathrm{l}$ of $10 \%$ the aluminium chloride solution and followed by $150 \mu \mathrm{l}$ of $96 \%$ ethanol. $10 \mu \mathrm{l}$ of $1 \mathrm{M}$ sodium acetate was added to the mixture in a 96 well plate. $96 \%$ ethanol was used as reagent blank. All reagents were mixed and incubated for $40 \mathrm{~min}$ at room temperature protected from light. The absorbance was measured at $415 \mathrm{~nm}$ with a microplate reader (Versamax Microplate Reader, USA). Total flavonoid contents were expressed as mg Quercetin Equivalents (QE) per g of plant extract.

\section{Determination of Total Phenolic Content}

The microplate total phenolic content method was based on the 96-well microplate Folin-Ciocalteu method adapted from Ahmad et al ${ }^{20}$ with some modifications. A total of $25 \mu \mathrm{L}$ of the diluted extract of each part of $C$. bonduc were mixed with $100 \mu \mathrm{L}$ of 1:4 diluted Folin-Ciocalteu reagent and shaken for $60 \mathrm{sec}$ in a flat-bottom 96-well microplate. The mixture was left for 240 secs and then $75 \mu \mathrm{L}$ of sodium carbonate solution $(100 \mathrm{~g} / \mathrm{L})$ were added and the mixture was shaken at mediumcontinuous speed for $1 \mathrm{~min}$. After $2 \mathrm{~h}$ at room temperature, the absorbance was measured at $765 \mathrm{~nm}$ using the microplate reader (Versamax Absorbance Microplate Reader, USA). The absorbance of the same reaction with ethanol instead of the extract or standard was subtracted from the absorbance of the reaction with the sample. Gallic acid dilutions (10-200 $\mathrm{mg} / \mathrm{L})$ were used as standards for calibration. Total phenolic contets were expressed as mg Gallic Acid Equivalents (GAE) per g of plant extract.

\section{Antioxidant activity}

DPPH scavenging ability assay was used to evaluate the antioxidant activity of each extract. Test was conducted in a 96-well plate according to Zahratunnisa et al. ${ }^{21}$ with slight modification. $20 \mu \mathrm{L}$ stock solution of extracts in different concentrations (100, 500, 1000, 1500, 2000 ppm) and $180 \mu \mathrm{L}$ of DPPH solution $0.147 \mathrm{mM}$ were added to each well. After 30 min incubation at room temperature in dark room, absorbance was read at $517 \mathrm{~nm}$ using micro-plate reader of Versamax Microplate Reader (USA). Methanol was used as blank. The scavenging ability (\%) was calculated as follows:

$\%$ Inhibition $=\frac{\text { Absorbance of } \mathrm{stan} \text { dard }- \text { Absorbance of crude extract }}{\text { Absorbance of standard }} \times 100$

Ascorbic acid was used as positive standard. All tests were performed in triplicate. Concentration of samples resulting in 50\% inhibition on $\mathrm{DPPH}\left(\mathrm{IC}_{50}\right.$ value) were calculated.

\section{RESULTS}

\section{Percentage Yield of Extract}

The results showed the highest yield was associated with leaves (33.8\%), followed by seed kernel (28.26\%), root (18.52\%) and then stem (10.48\%) as seen on Figure 2.

\section{Phytochemical screening}

The extracts were further investigated to determine phytochemical compound in the extract. The common phytochemistry content from plant such as flavonoid, alkaloid, terpenoid, steroid, tannin, and saponin have identified (Table 1).

\section{Total Flavonoid Content}

The result of total flavonoid contents of the four crude extracts is given in Table 2. Equation of calibration curve of quercetin standard was $\mathrm{y}=0.0291 \times-0.0397, \mathrm{R}^{2}=0.9904$.

Among the four crude extracts, leaf contained the highest $(31.05 \pm 0.35$ $\mathrm{mgQE} / \mathrm{g}$ ) amount of total flavonoid content compounds followed by stem $(21.82 \pm 0.46)$, seed kernel $(13.21 \pm 1.35)$ and then root $(12.55 \pm$ $0.08 \mathrm{mgQE} / \mathrm{g})$.

\section{Total Phenolic Content}

The result of total phenolic content determination from $70 \%$ ethanolic extracts of different parts of C. bonduc are shown in Table 3. Calibration curve from gallic acid showed maximum absorbances at $765 \mathrm{~nm}$ wavelength (equation $\mathrm{y}=0.0531 \mathrm{x}+0.0003, \mathrm{R}^{2}=0.9951$ ).

The total phenol contents of four crude extracts determined by FolinCiocalteu method were reported as gallic acid equivalents. Among the four crude extracts, leaf contained the highest (146.64 $\pm 3.94 \mathrm{mgGAE} / \mathrm{g})$ amount of total phenolic content compounds followed by stem (144.42 


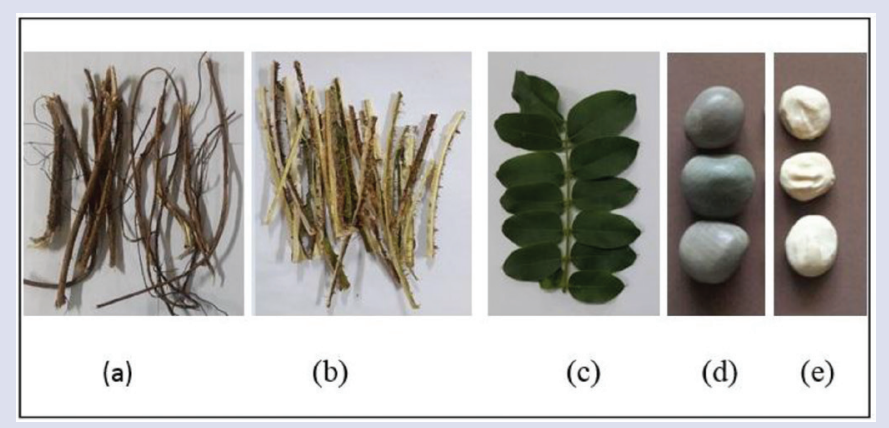

Figure 1: Caesalpinia bonduc (L.) Roxb (a) root; (b) stem; (c) leaf; (d) seed; (e) seed kernel.

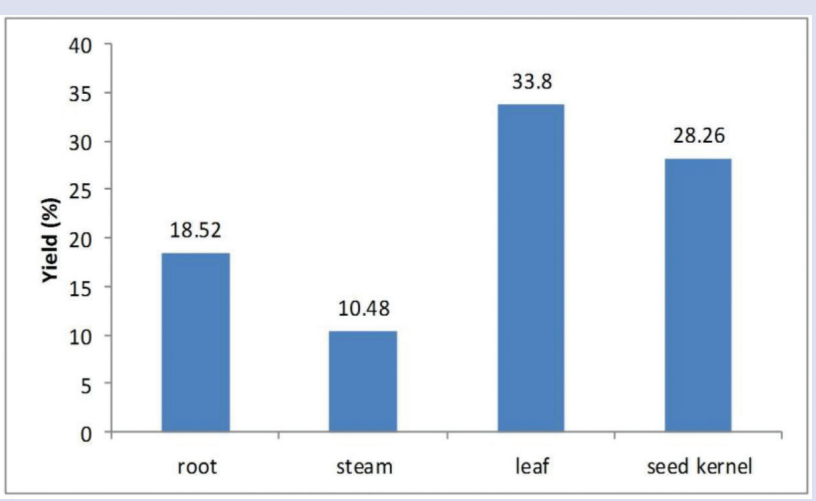

Figure 2: Percentage of yield.

$\pm 16.05)$, root $(89.81 \pm 3.00)$ and then seed kernel $(70.34 \pm 10.59$ mgGAE/g).

\section{Antioxidant Activity}

The ability of extract in scavenging DPPH radical are shown in Table 4. The leaf has the highest ability to scavenge free radicals than other parts.

\section{DISCUSSION}

Extraction was done using $70 \%$ ethanol as solvent. According to Jing et $a l,{ }^{22}$ this solvent is preferred to extract phenolic compounds from plants. Reflux method was chosen as extraction method to optimize phenolic and flavonoid content. Temperature was maintained not exceeding $70^{\circ} \mathrm{C}$ to avoid any degradation of phenolic and flavonoid as targeted compound. ${ }^{23}$

Different parts of plant could have different phytochemical compound, which may contribute to different pharmacological effect of each part. Phytochemical screening showed that all of extracts from root, stem, leaf and seed kernel of $C$. bonduc contain flavonoid and saponin, and absent in alkaloid and quinone. Among other part, only leaf contained tannin, one of polyphenol that can donate hydrogen and act as antioxidant. ${ }^{15,24}$

Total flavonoid content was determined using aluminium chloride method. Aluminium chloride will form stable complex with carbonyl group at C4 and hydroxyls at C3 (flavonols) and C5 in flavonols and flavones. It could also form labile acid complexes with hydroxyls in the ortho position in $\mathrm{B}$ rings of flavonoids. ${ }^{25}$
Table 1: Phytochemical screening of the extracts.

\begin{tabular}{ccccc}
\hline $\begin{array}{c}\text { Phytochemical } \\
\text { Constituents }\end{array}$ & Root & Stem & Leaf & $\begin{array}{c}\text { Seed } \\
\text { kernel }\end{array}$ \\
\hline $\begin{array}{c}\text { Alkaloids } \\
\text { Flavonoid }\end{array}$ & - & - & - & - \\
Saponin & + & + & + & + \\
Triterpenoids & + & + & + & + \\
Steroid & - & - & + & + \\
Tannin & - & - & + & + \\
Quinone & - & - & - & - \\
\hline
\end{tabular}

Note: - $=$ absent, $+=$ present

Table 2: Total Flavonoid Content.

\begin{tabular}{cc}
\hline Sample & Total Flavonoid Content (mgQE/gram) \\
\hline Root & $12.55 \pm 0.08$ \\
Stem & $21.82 \pm 0.46$ \\
Leaf & $31.05 \pm 0.35$ \\
Seed kernel & $13.21 \pm 1.35$ \\
\hline
\end{tabular}

Data are mean \pm SEM for triplicate measurements.

Table 3: Total Phenolic Content.

\begin{tabular}{cc}
\hline Sample & Total Phenolic Content (mgGAE/gram) \\
\hline Root & $89.81 \pm 3.00$ \\
Stem & $144.42 \pm 16.05$ \\
Leaf & $146.64 \pm 3.94$ \\
Seed kernel & $70.34 \pm 10.59$ \\
\hline
\end{tabular}

Data are mean \pm SEM for triplicate measurements.

Table 4: Antioxidant DPPH Scavenging Activity.

\begin{tabular}{cc}
\hline Sample & $\mathrm{IC}_{50}(\mu \mathrm{g} / \mathrm{mL})$ \\
\hline Root & 135,778 \\
Stem & 169.92 \\
Leaf & 79,802 \\
Seed kernel & $>200$ \\
Ascorbic acid & 2.24 \\
\hline
\end{tabular}

The total phenols contents in four different crude extracts were evaluated in the present study. The highest amount of phenolics compounds was present in leaf (146.64 mg of GAE/g of crude extract) and the lowest was in seed kernel extract (70.34 mg of GAE/g). Leaf also have highest total flavonoid content $(31.05 \pm 0.35 \mathrm{mgQE} / \mathrm{g})$ while the lowest was in root (12.55 $\pm 0.08 \mathrm{mgQE} / \mathrm{g})$.

The molecule DPPH is a free radical by the delocalisation of the spare electron over the molecule. The delocalization of electron rises to the deep violet colour. If a solution of DPPH is mixed with samples that can donate a hydrogen atom, DPPH will be converted into colourless purple. The amount of reduced DPPH was measured in absorbance at $517 \mathrm{~nm} .^{26}$ In present study, ascorbic acid as a well known potent antioxidant, was used as positive control for DPPH scavenging activity. Leaf part showed highest ability in DPPH scavenging activity compare to other plant part which measured by the lowest $\mathrm{IC}_{50}$ value, but it has lower antioxidant capacity compared to ascorbic acid. The phenolic content in the leaf may contribute to the antioxidative action by hydrogen donating ability. Antioxidant activity of leaf and seed kernel of $C$. bonduc in this study were found different from study in other country. ${ }^{27,28}$ The variation might be 
caused by different phytogeographic region and plant nutrition, which could modify the secondary metabolites of the plant $\mathrm{t}^{29}$ and due to the different method of extraction and solvents polarities.

\section{CONCLUSION}

The $70 \%$ ethanol leaf extract of C. bonduc showed the highest yield, total flavonoid content and total phenolic content compared to other part investigated. Moreover, leaf extract has highest DPPH free radical scavenging activity $(79.802 \mu \mathrm{g} / \mathrm{mL})$ which could be related to its higher phenolic content.

\section{ACKNOWLEDGEMENT}

This study was supported by Universitas Indonesia via a grant "Hibah PITTA 2017".

\section{CONFLICT OF INTEREST}

No conflict of interest

\section{ABBREVIATION USED}

C. bonduc: Caesalpinia bonduc L. Roxb; GAE: Gallic acid equivalent; QE: Quercetin equivalent, DPPH: 1,1-diphenyl-2-picrylhydrazyl; IC $_{50}$ : Concentration of samples resulting in $50 \%$ inhibition.

\section{REFERENCES}

1. Zanin JLB, Carvalho BA, Martineli PS, Dos-Santos MH, Lago JH, Sartorelli P, et al. The genus Caesalpinia L. (Caesalpiniaceae): phytochemical and pharmacological characteristics. Molecules. 2012;17(7):7887-902. DOI:10.3390/molecules17077887.

2. Singh V, Raghav PK. Review on pharmacological properties of Caesalpinia bonduc L. Int J. Med Arom Plants. 2012;2(3):514-30.

3. Nazeerullah K, Suni K, Pal RS, Neelam D. Review Article : A pharmacognostic and pharmacological overview on Caesalpinia bonducella. Research. Journal of Pharmaceutical. Biological and Chemical Sciences. 2012;3(1):480-96.

4. Elfahmi, Woerdenbag HJ, Kayse O. Jamu: Indonesian traditional herbal medicine towards rational phytopharmacological use: review. Journal of Herbal Medicine. 2014;4(2):51-73. http://dx.doi.org/10.1016/j.hermed.2014.01.002.

5. Kakade NR, Pingale SS, Chaskar MG. Phytochemical and pharmacological review of Caesalpinia bonducella. International Research Journal of Pharmacy. 2016;12:12-7.

6. Mardisiswojo S, Mangunsudarso HR. Cabe Puyang Warisan Nenek Moyang. Balai Pustaka. 1985. (In Bahasa)

7. Heyne K. The Useful Indonesian Plants. Sec Edition. Research and Development Agency, Ministry of Forestry, Indonesia: Jakarta; 1987. (In Bahasa)

8. Amudha P, Bharathi NP, Vanitha V. Caesalpinia bonducella-A review on pharmacological and phytochemical activity of seeds. Inter J Pharm Bio Sci. 2016; 7(4):674-80

9. Awale S, Linn TZ, Tezuka Y, Kalauni SK, Banskota AH, Attamimi F, et al. Constituents of Caesalpinia crista from Indonesia. Chemical and Pharmaceutical Bulletin. 2006;54(2):213-8.

10. Kasahara YS, Mangunkawatja S. Medicinal Herb Index in Indonesia. PT Eisai Indonesia. Jakarta. 1986.p.140.
11. Moon K, Khadabadi SS, Deokate UA, Deore SL. Caesalpinia bonducella F - An Overview. Report and Opinion. 2010;2(3):83-90.

12. Suryawanshi HP, Patel MR. Traditional Uses, Medicinal and Phytopharmacological Properties of Caesalpinia crista Linn - An Overview. International Journal of Research in Pharmacy and Chemistry. 2011;1(4):1179-83.

13. Lobo V, Patil A, Phatak A, Chandra N. Free radicals, antioxidants and functional foods: Impact on human health. Pharmacognosy Rev. 2010;4(8):118-26. DOI: 10.4103/0973-7847.70902

14. Alam MN, Bristi NJ. Review on in vivo and in vitro methods evaluation of antioxidant activity. Saudi Pharmaceutical Journal. 2013;21(2):143-52. http://dx.doi. org/10.1016/j.jsps.2012.05.002.

15. Ghalem M, Merghache S, Belarbi M. Study on the antioxidant activities of root extracts of Zizyphus lotus from the western region of Algeria. Pharmacognosy J. 2014;6(4):32-42. DOI: 10.5530/pj.2014.4.5

16. Departemen Kesehatan Republik Indonesia. Materia Medika Indonesia Jilid VI. 1995. (In Bahasa)

17. Harborne JB. Phytochemical methods A guide to modern techniques of plant analysis. Third ed. Chapman and Hall. 1998;204-8.

18. Chatattikun M, Choabchalard A. Phytochemical screening and free radical scavenging activities of orange baby carrot and carrot (Daucus carota Linn) root crude extracts. Journal of Chemical and Pharmaceutical Research. 2013;5(4):97-102.

19. Roy S, Pawar S, Chowdary A. Evaluation of in vitro Cytotoxic and Antioxidant Activity of Datura metel/Linn. and Cynodon dactylon Linn. Extracts. Pharmacognosy Res. 2016;123-7. doi: 10.4103/0974-8490.175610.

20. Ahmad I, Yanuar A, Mulia K, Mun'im A. Application of ionic liquid as a green solvent for polyphenolics content extraction of Peperomia Pellucida (L) Kunth Herb. J Young Pharm. 2017;9(4):486-90. DOI: 10.5530/jyp.2017.9.95.

21. Zahratunnisa N, Elya B, Noviani A. Inhibition of alpha glucosidase and antioxidant test of stem bark extracts of Garcinia fruticosa Lauterb. Pharmacogn J. 2017;9(2):273-5. http://dx.doi.org/10.5530/pj.2017.2.46.

22. Jing L, Ma H, Fan P, Gao R, Jia Z. Antioxidant potential, total phenolic and total flavonoid contents of Rhododendron anthopogonoides and its protective effect on hypoxia-induced injury in PC12 cells. Bio Med Central Complementary and Alternative Medicine. 2015;15(1):287. DOI 10.1186/s12906-0150820-3.

23. Ghasemzadeh A, Jaafar H. Optimization of reflux conditions for total flavonoid and total phenolic extraction and enhanced antioxidant capacity in pandan (pandanus amaryllifolius roxb.) using response surface methodology. The Scientific World Journal. 2014;1-10. http://dx.doi.org/10.1155/2014/523120.

24. Zhang $S$, Lin $Y$, Zhou $H$, Wei S, Lin G, Ye G. Antioxidant tannins from stem bark and fine Root of Casuarina equisetifolia, Molecules, 2010;15(8):5658-70. DOI:10.3390/molecules15085658.

25. Chang $\mathrm{CH}$, Yang MH, Wen HM, Chern JC. Estimation of total flavonoid content in propolis by two complementary colorimetric methods. Journal of Food and Drug Analysis. 2002;10(3):178-82.

26. Sharma A, Bhardwaj S, Mann AS, Jain A, Kharya MD. PhCog Rev: Review article screening methods of antioxidant activity: An overview. Pharmacognosy Review. 2007;1(2).

27. Mandal S, Hazra B, Sarkar R, Biswas S, Mandal N. Assessment of the antioxidant and reactive oxygen species scavenging activity of methanolic extract of Caesalpinia crista Leaf. Evidence-Based Complementary and Alternative Medicine. 2011, Article ID 173768. DOI:10.1093/ecam/nep072

28. Shukla S, Mehta A, John J, Singh S, Mehta P, Vyas SP. Antioxidant activity and total phenolic content of ethanolic extract of Caesalpinia bonducella seed kernels. Food and Chemical Toxicology. 2009;47(8):1848-51. DOI: 10.1016/j. fct.2009.04.040.

29. Zhang X, Zhao Y, Guo L, Qiu Z, Huang L, Qu X. Differences in chemical constituents of Artemisia annua $L$ from different geographical regions in China. PLoS ONE. 2017;12(9):e0183047. https://doi.org/10.1371/journal.pone.0183047.

\section{GRAPHICAL ABSTRACT}

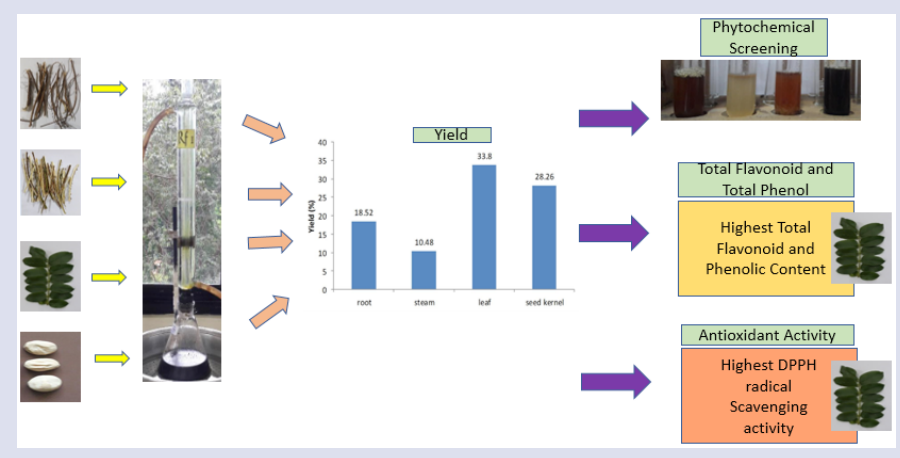

\section{SUMMARY}

- Each part of $C$. bonduc (root, stem, leaf, seed kernel) were extracted by reflux using $70 \%$ ethanol as the solvent for 2 hours and repeated 3 times.

- The highest yield was leaf (33.8\%). Phytochemical screening showed that all of samples positively contain flavonoid and saponin.

- Total flavonoid content was the highest in leaf $(31.05 \pm 0.35 \mathrm{mgQE} / \mathrm{g})$ and the lowest in root whereas total phenols content was highest in leaf (146.64 \pm $3.94 \mathrm{mgGAE} / \mathrm{g}$ ) and the lowest in seed kernel.

- The highest DPPH free radical scavenging activity was in leaf extract $(79.802$ $\mu \mathrm{g} / \mathrm{mL}$ ) followed by root, stem, and seed kernel. 


\section{ABOUT AUTHORS}

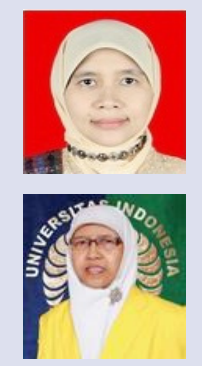

Elin Novia Sembiring: Is a magister student at the Faculty of Pharmacy, University of Indonesia. Her magister research focused on the phytochemical and antioxidant activity of Indonesian herbal medicines.

Berna Elya: Is Professor at the Faculty of Pharmacy, University of Indonesia. She is Head of Laboratory of Phytochemistry and Pharmacognosy. Has expertise in the area of Pharmacognosy and Phytochemistry of Natural Products.

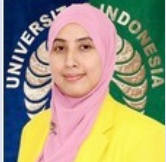

Rani Sauriasari: working as lecturer and researcher in Faculty of Pharmacy, University of Indonesia. Her doctor degree obtained from Public Health (Medical Faculty), Okayama University, Japan. Currently, she is positioned as Manager of Research and Community Engagement, Faculty of Pharmacy, University of Indonesia. Has experience in the area of Biochemistry, Analitycal Chemistry and Pharmacology, working mainly in: Medicinal plants and New Research Drugs.

Cite this article: Sembiring EN, Elya B, Sauriasari R. Phytochemical Screening, Total Flavonoid and Total Phenolic Content, and Antioxidant Activity of Different Parts of Caesalpinia bonduc (L.) Roxb. Pharmacog J. 2018;10(1):123-7. 